\title{
Correspondence
}

To the Editors

\section{Passive immunity from immunised mother: A nano-structural consideration on transplacental and breast milk passage to neonate}

Sri Lanka Journal of Child Health, 2021: 50(4): 745-746

DOI: http://doi.org/10.4038/sljch.v50i4.9907

(Key words: Passive immunity, Transplacental, Breast milk, Neonate)

Dear Editors,

Immunization against COVID-19 by vaccination is a good way of controlling the pandemic. However, COVID-19 vaccine is not currently recommended for the newborn. How to promote immunity in the newborn is very interesting. At present, COVID-19 vaccination has proven safe and it is planned to be used in pregnant mothers ${ }^{1,2}$. The passage of passive immunity to the neonate is an interesting phenomenon. In brief, there are two main passages of passive immunity from mother to neonate either via breastmilk or transplacental.

The passage of passive immunity from an immunised mother to her baby through immunoglobulin occurs if it is physiologically permitted. In the case of COVID-19, there is very little knowledge on this issue. Using the basic nanoanatomy concept, a theoretical explanation can be given. Basically, an immunoglobin can pass via breast milk or transplacentally if it has a size smaller than breast milk pores or placental pores. This is a similar phenomenon to explaining transplacental transmission or transmission via breast milk of a pathogen $^{3,4}$.

Here, the authors use a clinical simulation for explaining passive immunity from the immunized mother. After vaccinating a mother, the protective antibody is immunoglobulin $\mathrm{G}$ ( $\mathrm{IgG}$ ) neutralizing antibody. The size of the antibody is about $14 \mathrm{~nm}^{5,6}$. Comparing this nano-size to the mammary gland pores (about $400 \mathrm{~nm}$ ) and placental pores (about 300 $\mathrm{nm})$, the protective IgG is smaller and can pass thorough the pores to the neonate. Additionally, it can be seen that immunity can pass thorough breastmilk easier than through the transplacental route. Based on nano-anatomy, passage via breastmilk should be 1.3 times more likely to occur than transplacental. This confirms that maternal immunization plays an important role for promoting neonatal immunity against COVID-19. Also, since passive immunity seems to be better passed via breastmilk, breast feeding of an immunized mother is recommended.

\section{References}

1. Pramanick A, Kanneganti A, Wong JLJ, Li SW, Dimri PS, Mahyuddin AP, et al. A reasoned approach towards administering COVID-19 vaccines to pregnant women. Prenatal Diagnosis 2021 June 15. Online ahead of print.

https://doi.org/10.1002/pd.5985

PMid: 34191294

2. Brillo E, Tosto V, Gerli S, Buonomo E. COVID-19 vaccination in pregnancy and postpartum. Journal of Maternal-Fetal and Neonatal Medicine 2021 June 21:1-21. Online ahead of print. https://doi.org/10.1080/14767058.2021.19 37991

PMid: 34154501

3. Tan YH, Liu M, Nolting B, Go JG, Hague JG, Liu GY. Nanoengineering approach for investigation and regulation of protein immobilization. ACS Nano 2008; 2(11): 2374-84.

https://doi.org/10.1021/nn800508f

PMid: 19206405 PMCid: PMC4512660

4. Sriwijitalai W, Wiwanitkit V. Comparative nanostructure consideration on novel coronavirus and possibility of transplacental transmission. American Journal of Obstetrics and Gynecology 2020; 223(6): 955.

https://doi.org/10.1016/j.ajog.2020.08.061

PMid: 32858014 PMCid: PMC7446665

5. Joob B, Wiwanitkit V. Zika virus infection and breastfeeding. Annals of Tropical Medicine and Public Health 2017; 10: 752. https://doi.org/10.4103/1755-6783.208699 
6. Jalkanen P, Kolehmainen P, Häkkinen HK, Huttunen M, Tähtinen PA, Lundberg R, et al. COVID-19 mRNA vaccine induced antibody responses against three SARSCoV-2 variants. Nature Communications 2021; 12(1): 3991.

https://doi.org/10.1038/s41467-021-

24285-4

PMid: 34183681
*Somsri Wiwanitkit ${ }^{1}$, Viroj Wiwanitkit ${ }^{2}$

${ }^{1}$ Private Academic Consultant, Pune, India ${ }^{2}$ Honorary Professor, Dr. DY Patil University, Pune, India and Adjunct professor, joseph Ayobabalola University, Ikeji-Arakjei, Nigeria

*Correspondence: somsriwiwan@hotmail.com (iD) https://orcid.org/0000-0002-9486-9473

The author declares that there are no conflicts of interest.

Open Access Article published under the Creative Commons Attribution CC-BY C) (i) License 